\title{
7 \\ Nashe and Harvey in Illyria
}

I've suggested that in As You Like It Shakespeare etched into Touchstone an effigy of Thomas Nashe. I will show that in Twelfth Night Shakespeare produced another, more highly developed portrait of Nashe as Feste - and thrust him back into conflict with his real-life nemesis Gabriel Harvey, whom Shakespeare cast as Malvolio - 'He who wishes evil' - the pretentious, over-ambitious steward. We will find that Shakespeare has drawn a Pauline FesteNashe with an adroitness and sophistication which leaves one quite awestruck, and that he derived his caricature of Malvolio-Harvey (and the letter-plot that precipitates his downfall) from accounts of Harvey's follies published by Nashe. By so doing, Shakespeare enabled the departed Nashe to continue to persecute and torment his bete noire. I will also show that Shakespeare blended Nashe and Paul to create an extraordinary fool whose humour, gravitas, and ultimate pathos surpass anything in Touchstone - and did so by exploiting the Epistles to the Corinthians.

\section{A Pauline Feste}

Circa AD 5, the theologian we know as St Paul was born Saul, a Jew and Roman citizen, in Tarsus, south-central Turkey, a dozen miles from the sea; in Antony and Cleopatra Shakespeare remembers that illustrious couple's fateful meeting on Tarsus's River Cydnus. Saul was a compulsive wanderer who was to scour Asia Minor preaching the faith of Jesus. But he began his travels in his youth and was raised a Pharisee in Jerusalem, where he studied with Rabbi Gamaliel, so he was predisposed to believe in the resurrection of the dead. ${ }^{1}$ Young Saul deplored Christians and became an enthusiastic persecutor of the sect. He is thought to have been the man who 
guarded the clothes of the mob who stoned Saint Stephen circa AD 35 (Acts 7:58).

On his way to Damascus Saul-Paul's wanderings took an unexpected turn. In Acts 9:1-2, Luke writes that 'Saul yet breathing out threatnings and slaughter against the disciples of ye Lord, went vnto the hie Priest, And desired of him letters to Damascus to the Synagogues, that if he found any that were of that way [Christians] (either men or women) hee might bring them bound vnto Hierusalem.' But en route a miracle occurred: 'Now as he iourneyed, it came to passe that as he was come neere to Damascus, suddenly there shined rounde about him a light from heauen. And hee fell to the earth, and heard a voyce, saying to him, Saul, Saul, why persecutest thou me?' (9:3-4). Blinded and taken to Damascus to heal, Saul was converted to Christianity, renamed himself Paul, and, after bitter disagreements with Peter, appointed himself 'Apostle to the Gentiles' and embarked on a career as a peripatetic missionary. He brought the good news to places as distant as Illyricum and Rome. $^{2}$

Paul was an inveterate nomad, a professional wanderer. The first thing we learn about Feste is that he's a wanderer. Maria chides him, 'Nay, either tell me where thou hast been, or I will not open my lips so wide as a bristle may enter in way of thy excuse: my lady will hang thee for thy absence' (1.5.1-3). Feste won't say where he's been, nor does he cease wandering; throughout the play he is back and forth between the houses of Olivia and Orsino. We cannot be sure whether Nashe was himself a traveller; his most distant destination seems to have been Yarmouth, 140 miles north of London. But in The Unfortunate Traveler, or the Life of Jack Wilton (1594), Nashe - writing in the first person - fantasized wide-ranging travels in both space and time. ${ }^{3}$ Perhaps Jack Wilton was the link in Shakespeare's mind connecting Nashe to the peripatetic life.

Paul was also the New Testament authority on things foolish. 'Fool' and its variants appear forty-one times in the New Testament thirty-one of those in the writings of Paul, and most of these in his 'Call me fool' letters to the Corinthians. Twelfth Night is Shakespeare's great play about fools, foolishness, and foolery; the word 'fool' and its variants appear in this play more than seventy times, far more than in any other play in the canon. And the fool in charge of fooling (and perhaps the wisest character) is Feste. I will show that Shakespeare conceived Feste as a Pauline 'Fool' - a wise 
man in motley - and that he is not merely quick of wit and glib of tongue, but also the bringer of good news to Illyria.

\section{Moth as rehearsal for Feste}

Shakespeare rehearsed his portrayal of Nashe in Love's Labour's Lost; he wrote a warm, light-hearted miniature of his friend into the character of Moth (an anagram of Thom). Like Thom, Moth is small of stature, sharp of mind and tongue, and a masterful debunker of ignorance as personified by his master, the original bloviating ignoramus, Don Adriano de Armado. The play was written in 1595-96; Shakespeare's likeness of Nashe may have been sufficiently transparent for many of his first auditors to recognize. Those who conned Nashe as Moth likely detected Nashe's persistent literary opponent, Gabriel Harvey, behind the mask of Armado. Since 1592 Nashe and Harvey had achieved estimable notoriety through their no-holds-barred exchange of vitriolic pamphlets. And Nashe was very much a man-about-London; he hadn't yet written his share of The Isle of Dogges - perhaps a sortie into class warfare which dispatched him into self-imposed internal exile. Furthermore - and this is the heart of the matter - Nashe was a friend of Shakespeare and Harvey not. Scholars now generally accept Thom as the model for Moth, and should recognize Harvey lampooned in Armado. ${ }^{4}$ But what has gone unnoticed is that Shakespeare once again pitted Nashe against Harvey in Twelfth Night.

\section{Portraits of Nashe, pre- and post-mortem}

When Shakespeare wrote Twelfth Night - most likely in the latter half of 1601 - both Nashe and Harvey had been silenced two years and Nashe was dead. We do not know the date of his death; we lose sight of him after the publication of Nashes Lenten Stuffe and the burning of his and Harvey's books in the summer of 1599. The consensus holds that Nashe died in the interval 1599-1601. Though he had been forbidden to publish, somehow Nashe's Summer's Last Will and Testament, written in 1592, was registered for publication by Cuthbert Burby on 28 October 1600 and emerged from the press before the end of that year with Nashe named as author. Perhaps because the pageant had been written for and performed at the residence of Archbishop Whitgift it was considered immune 
to sanction - or, more likely, because Nashe had recently died. The registration date of Summer's Last Will may set a date ad quem for Nashe's death, and would narrow it to between June 1599 and October 1600. If my inference that a still-living Nashe mocks the world from behind the mask of Touchstone, that further narrows the date of his death to between spring 1600 and October of that year. This may explain the stark difference between Shakespeare's portrait of Nashe as Touchstone in As You Like It - a man entirely without spiritual bent and Shakespeare's Feste-Nashe, the Pauline clown whose borrowings from the Gospels run from Mark to Galatians. ${ }^{6}$ It is also possible that the publication of Summer's Last Will called to mind the link between Sommers and Nashe which Shakespeare deftly exploited.

In 1996 Katherine Duncan-Jones discovered among papers at Berkeley Castle a previously unknown elegy for Nashe entitled 'To the dear memory of Th. Nashe from his dearest friend Ben Jonson'. It is not very well known and merits quoting in full:

Mortals that yet respire with plenteous breath

View here a trophee of that tyrant deathe

And let the obiect strike your melting eyes

blind as the night, when you but read, Here lies

Conquerd by destiny $\&$ turned to earthe

The man whose want hathe causd a generall dearthe

Of witte; throughout this land: none left behind

to equall hym in his ingenious kynd

I vrge not this as being his parasite

who lou'd him least will doe him greater right

Noe well deserving muse but will impart

her flowers to crown his Industrie \& art when any wrongd him lyuing they did feele his spirite quicke as powder sharp as stele But to his freindes her faculties were faire pleasant and milde as the most temp'rate ayre $\mathrm{O}$ pardon me deare freind yf fear controule the zealous purpose of my wounded sowle feare to be censured glorious in thie praise (A maime[d] sone taken in these hum'rous dayes where every dudgeon iudgement stabs at witt yette (for thie loue) this truth Ile not omitte Which most may make thie merites to appeare $\&$ ioye thie glad suruiuing freindes to heare), thou diedst a Christian faithfull penitent 
Inspir'd with happie thoughtes \& confident This though thie latest grace was not the least Which still shall lyue when all else are deceast farewell greate spirite my pen attird in blacke shall whilst I am still weepe \& mourn thie lacke [my emphasis]. ${ }^{7}$

If we may take Jonson at his word, Nashe found religion, he died 'a Christian faithfull penitent', and his 'grace' will live after him. Nashe's redemption explains and justifies Shakespeare's portrait of his friend as a Pauline fool.

The evolution of Shakespeare's Nashe from the jocular juvenile of Love's Labour's Lost to the cynical seducer of shepherdess Audrey in As You Like It to the Scripture-spouting wanderer of Twelfth Night may depict Nashe's personal (spiritual) journey. If so, the triptych constitutes a unique literary document, and one that deserves more thoughtful consideration than I can give it here. That Shakespeare created three portraits of Nashe suggests a close and influential bond between the men; so far as we know Shakespeare fashioned nothing of the kind for anyone else. ${ }^{8}$ It may be that Shakespeare felt as great a literary debt to Nashe as to Marlowe.

\section{The wisest fool}

I will surely find agreement when I suggest that Feste is the most intelligent, perceptive, and thoughtful character in the play. In every conversation from his first encounter with Maria to his final thrust at Malvolio, 'thus the whirlegigge of time, brings in his reuenges' (5.1.370) Feste comes out on top. In 3.1 he may see through Viola's disguise and recognize 'Cesario' is female. He perceives Viola's affection for Orsino and scents the Toby-Maria tryst. Feste is a bright mind and a 'corrupter of words'; Nashe was both. He tells Viola, 'wordes are growne so false, I am loath to proue reason with them' (3.1.23-4). Shakespeare dots Feste's dialogues with clues to the man behind the mask. ${ }^{9}$ Some are faint, as when Feste encounters Viola-Cesario:

Vio. Save thee, friend, and thy music: dost thou live by thy tabour?

Clo. No, sir, I live by the church.

Vio. Art thou a churchman?

Clo. No such matter, sir: I do live by the church; For I do live at my house, and my house doth stand by the church. (3.1.1-7) 
Nashe being redeemed, dead, and buried, his house (grave) would stand in a churchyard. The Grave-digger in Hamlet boasts: 'the houses that he makes last 'til doomsday' (5.1.55). But Feste's dialogue is also painted with the colours of St Paul:

Vio. I warrant thou art a merry fellow and carest for nothing.

Clo. Not so, sir, I do care for something; but in my conscience, sir, I do not care for you. (3.1.25-8)

The Christian conscience was a Pauline conception. It was Paul in 1 Corinthians who commanded a Christian taking Holy Communion to first clear his conscience: 'Let euery man therefore examine himselfe, and so let him eate of this bread, and drinke of this cup. For he that eateth and drinketh vnworthily, eateth and drinketh his owne damnation' (11:28-9).

Later in their scene Viola demands of Feste, 'Art not thou the Lady Olivia's fool?' and receives a Nashean reply:

Clo. No, indeed, sir; the Lady Olivia has no folly: she will keep no fool, sir, till she be married; and fools are as like husbands as pilchards are to herrings; the husband's the bigger: I am indeed not her fool, but her corrupter of words. (3.1.31-5)

The comparison of herrings with pilchards is a wink at Nashes Lenten Stuffe, in which he apotheosized the red herring at the expense of pilchards: 'if Cornish pilchards, otherwise called fumados ... be so saleable as they are in France, Spain and Italy (which are but counterfeits to the red herring, as copper to gold, or occamy to silver), much more their elbows itch for joy when they meet with the true gold, the true red herring itself' $(3 \cdot 1.7-13) .{ }^{10}$ Then Shakespeare swings Feste's pendulum back towards Paul and the ubiquity of fools; he declares, 'Foolery, sir, does walk about the orb like the sun, it shines every where' (37). Viola has had enough. She breaks off, saying, 'Nay, an thou pass upon me, I'll no more with thee. Hold, there's expenses for thee.' But Feste would have more than one coin:

Clo. Would not a pair of these have bred, sir?

Vio. Yes, being kept together and put to use.

Clo. I would play Lord Pandarus of Phrygia, sir, to bring a Cressida to this Troilus.

Vio. I understand you, sir; 'tis well begged.

Clo. The matter, I hope, is not great, sir, begging but a beggar:

Cressida was a beggar. (3.1.48-54). 
Paul was a beggar, too. As noted, he begged of the Corinthians in 1 Corinthians 16:1-2. A few scenes later, Sebastian will likewise try to buy his way out of a confrontation with Feste:

Seb. I prithee, foolish Greek, depart from me: There's money for thee: if you tarry longer, I shall give worse payment.

Clo. By my troth, thou hast an open hand. These wise men that give fools money get themselves a good report - after fourteen years' purchase. (4.1.17-22)

Sebastian's jibe at Feste as a 'foolish Greek' is as fitting an epithet for the anagrammatizing Feste as for Paul, the peripatetic Fool for Christ. Though born Sha'ul - as he describes himself, 'a Hebrew born of Hebrews' (Philippians 3:5) - Paul changed his name to the Greek $\Pi \alpha \tilde{\nu} \lambda o \varsigma=$ Paulos (Acts 13:9). Paul's everyday language may have been Greek, the lingua franca of the Roman Empire. His Epistles were certainly written in Greek; his translator, St Jerome (AD 347420), groaned that Paul's Greek was inelegant and clumsy. ${ }^{11}$

Feste's reference to 'fourteen years' has mystified commentators. But this is another of Shakespeare's winks at Paul. During his missionary journeys Paul begged and gathered alms for Peter, John, and the 'Jerusalem faction' of early Jewish Christians. And, indeed, he returned to Jerusalem with the money - after fourteen years: 'Then fourteene yeeres after, I went vp againe to Hierusalem with Barnabas' (Galatians 1:2). After some debate, Paul and his donation received a warm welcome from the Apostles: 'And when Iames, and Cephas [Peter], and Iohn, knew of the grace [alms, money] that was giuen vnto me ... they gaue to me and to Barnabas the right hands of fellowship, that we should preach vnto the Gentiles, and they vnto the Circumcision' (2:9). Paul bought his way into the Apostles' club.

There's an impious play on words in Feste's speech which commentators have overlooked. It appears in his phrase 'these wise men that give fools money'. In Paul's parlance of inversion ' wise men' = fools, and 'fool' = Paul. To be 'a fool for Christ' one must believe in the crucifixion and resurrection. Glib Feste is saying that believers are foolish to donate their money to Paul only to get a 'good report' to the 'Saintes' in Jerusalem after fourteen years.

Feste begs again in 5.1, this time from Orsino. After the Duke refuses him more than two coins, Feste turns the conversation towards sin: 
$D u$. You can foole no more money out of mee at this throw: if you will let your Lady know I am here to speak with her, and bring her along with you, it may awake my bounty further.

Clo. Marry sir, lullaby to your bountie till I come a-gen. I go sir, but I would not haue you to thinke, that my desire of hauing is the sinne of couetousnesse: but as you say sir, let your bounty take a nappe, I will awake it anon. (37-45).

Feste's reference to the 'sinne of couetousnesse' recalls one of Paul's passages that has become proverbial; in Timothy 6:7-10 - which the Geneva glosses as 'Against couetousnes' - Paul wrote: 'For the desire of money is the roote of all euill, which while some lusted after, they erred from the faith, and pearced themselues through with many sorowes.' So Feste is touching the heart of the Pauline notion of sin and evil as he decries covetousness.

When Viola sums up the character of Feste she offers us a thumbnail of Nashe - but her punchline is pure St Paul:

This fellow is wise enough to play the fool;

And to do that well craves a kind of wit:

He must observe their mood on whom he jests,

The quality of persons, and the time,

And, like the haggard, cheque at every feather

That comes before his eye. This is a practise

As full of labour as a wise man's art

For folly that he wisely shows is fit;

But wise men, folly-fall'n, quite taint their wit. (3.1.57-66)

What Viola closes on is a wink at Paul in 1 Corinthians 3:19-20: '[T]he wisdome of this worlde is foolishnesse with God: for it is written, He catcheth the wise in their owne craftinesse.' That Feste is Shakespeare's Pauline fool must have been transparent to his elite first auditors. And, doubtless, some recognized Nashe behind his motley. But Nashe-Feste also wears another disguise.

\section{Sommers as Nashe's red herring.}

Feste's name is mentioned only once in Twelfth Night: Curio's 'Feste, the jester, my lord; a fool that the lady Olivia's father took much delight in' (2.4.11-12). This is an allusion to fool Will Sommers' long service to Henry VIII. Shakespeare drops other hints at the fool's identity in Feste's first scene with Maria, which includes 
nods to both Nashe and Sommers. Maria warns the wanderer, 'my lady will hang thee for thy absence' (1.5.3). To Feste's quip 'He that is well hanged in this world needs to fear no colours ... [because] He shall see none to feare' (4-7), Maria replies, 'A good Lenten answer' (8), perhaps recalling Nashes Lenten Stuffe. Feste responds, 'Many a good hanging prevents a bad marriage; and, for turning away, let summer bear it out' (18-19, my emphasis). That final, awkward phrase has elicited painfully weak interpretations; for example, the pleasant summer weather would make Feste's dismissal bearable. I suggest that its awkwardness is Shakespeare's conspicuous hint - one might even say a sharp elbow - jogging his auditors to identify Feste, jester to the late father of 'Madonna' Olivia, with Sommer(s).

But if Shakespeare based the character of Feste on Thom Nashe, why does he drop these hints to Will Sommers? ${ }^{12}$ The answer may be this simple: Nashe had been banned, and it may not have been considered politic to stage a banned man or his writings before the Queen.

\section{Gabriel Harvey in Illyria}

Since the publication in 1980 of J. J. M. Tobin's iconic monograph, 'Gabriel Harvey in Illyria', the scholarly consensus accepts that Shakespeare modelled his ambitious steward on that pedant, selfstyled poet and critic, and social gadfly. ${ }^{13}$ Anyone who doubts that Harvey provided the model for Malvolio should weigh the evidence marshalled by Professor Tobin. He begins by demonstrating that the language of Twelfth Night is rife with borrowings from Nashe's pamphlets contra Harvey:

There are words and phrases in Twelfth Night, often unique or rare in the Shakespearean canon, which occur in An Almond for a Parrat (1590), Pierce Penilesse (1592), Strange Newes (1592), Have with you to Saffron-Walden (1596), and Nashes Lenten Stuffe (1599). An Almond for a Parrat, an anti-puritan pamphlet, provided Shakespeare in the composition of his play set in Illyria a reference to 'Illirians', the nouns 'sheepbyter', a term of abuse for puritans, 'souter', a similarly puritan-associated epithet, 'Brownist', 'bibble babble', the verb 'fadge(s)' the only other use of which in the canon occurs in Love's Labour's Lost, a play replete with Nashean echoes, and the adjectives 'malapert' and 'huperbolical'. ${ }^{14}$ 
But Tobin also demonstrates that Shakespeare's appropriations go beyond Nashe's diction. Each point in the Maria-Toby plot to humiliate Malvolio can be traced to a single episode in Nashe's satirical 'biographies' of Harvey.

In his Saffron-Walden, Nashe recounts that Harvey was jailed for debt in the Fleet. The circumstances were these: in response to Nashe's Pierce Pennilesse, Harvey dashed off Pierses Supererogation (1593). Nashe writes that Harvey promised to reimburse his printer, John Wolfe (1548?-1601), the cost of publication, £36. When Harvey repeatedly failed to pay up, Wolfe laid a trap to ensnare and arrest him.

The plot included a misleading letter. Nashe describes how Wolfe

went and feed baylies, and gets one Scarlet (a friend of his) to goe and draw him [Harvey] foorth, \& and hold him with a tale whiles they might steale on him \& arrest him ... and to the intent he [Harvey] might suspect nothing by Scarlets coming, there was a kind letter fram'd in Wolfes name, with To the right worshipfull of the Lawes, in a great Text hand, for a superscription on the out-side; and underneath at the bottome, Your worships ever to command, and prest to doo you service, John Wolfe. ${ }^{15}$

Wasn't this Shakespeare's inspiration for the forged letter that led to Malvolio's downfall? The reference to 'a great Text hand', the style of the salutation, and the inclusion of both a superscription and a subscription may have suggested to Shakespeare the form of Maria's letter, which begins with the superscription: 'To the unknown beloved' (2.5.90). Malvolio remarks on the penmanship: 'I think we do know the sweet Roman hand' (3.4.27). The letter also contains a postscript: 'Here is yet a postscript. Thou cans't not choose but know who I am ...' (2.5.169).

Nashe writes that while Harvey perused Wolfe's letter, two bailiffs 'stept into the roome boldly (as they were two well bumbasted swaggering fat-bellies, having faces as broad as the backe of a chimney, and as big as a towne bag-pudding) and clapping the Doctor with a lusty blow on the shoulder ... [cried] in Gods name and the Queenes wee doo arrest you'. ${ }^{16}$ In Twelfth Night 3.4, Toby dispatches Andrew to look for Viola-Cesario, saying, 'scout me for him at the corner the orchard like a bum-baily' (171-2) - the sole appearance of the term in the Shakespeare canon and the first recorded by $O E D$. Tobin is certainly correct to see this portmanteau 
word compounded by Shakespeare from Nashe's 'bum ... bellies' and 'baliffs'.

Carried off to the Fleet prison, Harvey carried on like a madman: 'O you prophane Plebeyans, exclaimed hee, I will massacre, I will crucifie you for presuming to lay hands thus on my reverent person. All this would not service him, no more than Hackets counterfeit madness woulde keep him from the Gallowes. ${ }^{17}$ After menacing the terrified wife of the jailer with his dagger, Harvey was finally subdued. Details from Nashe's report abound in Shakespeare's gulling and segregation of Malvolio from the forged letter and the term 'bum-baily' to Sir Topas-Feste's question, 'but tell me true, are you not mad indeed, or do you but counterfeit?' (4.2.114, my emphasis). Among many parallels cited by Tobin, he fails to notice that prisoners Harvey and Malvolio are both visited and freed by a divine. In Malvolio's case it is Feste as Sir Topas; Harvey had been freed by the intervention of 'the Minister then serving at Saint Albanes in Wood-street,' a man apparently surnamed Harvey who 'enterd bond for him to answere it at law, \& satisfied [paid] the House for his [Harvey's] lodging and Mangerie'. ${ }^{18}$

Summing up, Tobin characterizes Shakespeare's and Malvolio's debt to Nashe:

Because Shakespeare had read Nashe's works with interest, and, one suspects, admiration for their verbal pyrotechnics, he may well have recalled unconsciously some of the more striking words and phrases during his own writing. However, the large number of words and phrases present in Twelfth Night and unique in the canon and present also in Have with you to Saffron-Walden, a number of themes from pedantry to cowardice, insanity and presumption, and the central Malvolio-like character of Gabriel Harvey all suggest that Shakespeare read intentionally this most successful of Nashe's antiHarvey attacks, looking for materials which he could incorporate into his romantic comedy with its puritan gull. ${ }^{19}$

Once we have in hand Nashe's portrait of Harvey, it's easy to see how it shaped Shakespeare's invention of Malvolio's name. It is an Italian name compounded of mal, which signifies bad, evil, or ill, and voglio, the first person present of 'to wish' or 'to desire'. Queen Elizabeth had remarked that Harvey 'lookt like an Italian' (see the discussion below), and he certainly wished Nashe ill. Though Riche's Apolonius and Silla is accepted as the proximate source of 
Twelfth Night, Shakespeare's inspiration for the forged letter plot that gulled and humiliated Malvolio - including the mysterious M.O.A.I. - were drawn whole cloth from events in Harvey's life found in Nashe's Saffron-Walden.

\section{Feste's final lament}

When the comedy is ended, a stage direction indicates 'Exeunt' and Feste is left alone on stage. He begins to sing. And his song is an odd admixture of reminiscence, ribaldry, and pathos:

When that I was and a little tiny boy,

With hey, ho, the wind and the rain,

A foolish thing was but a toy,

For the rain it raineth every day.

But when I came to man's estate,

With hey, ho, \& c.

'Gainst knaves and thieves men shut their gate,

For the rain, \& $\mathrm{c}$.

But when I came, alas! to wive,

With hey, ho, \& c.

By swaggering could I never thrive,

For the rain, \& c.

But when I came unto my beds,

With hey, ho, \& c.

With toss-pots still had drunken heads,

For the rain, \& $c$.

A great while ago the world begun,

With hey, ho, \& c.

But that's all one, our play is done. (5.1.382-400)

The final line which appears in the Folio - 'And we'll strive to please you every day' - seems inappropriate for performance before a royal audience and, likely, was a later interpolation appropriate to a public playhouse (see the discussion below).

With Feste's lapse into silence the on-stage action concludes. Doubtless, auditors recognized his ditty as a parody of one of the best-loved passages in the New Testament, 1 Corinthians 13:11-13:

When I was a childe, I spake as a childe, I vnderstoode as a childe, I thought as a childe: but when I became a man, I put away childish thinges. For nowe we see through a glasse darkely: but then shall wee see face to face. Nowe I know in part: but then shall I know euen as I 
am knowen. And nowe abideth faith, hope and loue, euen these three: but the chiefest of these is loue.

If there had remained any doubt in the minds of Shakespeare's auditors that an incarnation of Paul stood before them, Feste's final song settled the matter. But what does Feste's song mean? What is it doing at the end of Twelfth Night? And why does it introduce an undeniable note of melancholy into an otherwise happy ending? Certainly, it locks the connection between Feste and Paul. But one must not forget Nashe also is present - and that, perhaps, explains its tone and abrupt caesura.

Of all the generations of scholarly brains flung at Feste's song, the clearest and most convincing interpretation is Verity's one-liner: 'My foolish deeds were thought little of when I was a boy: not so when I came to manhood; then men's doors were shut against me.'20 This could pass as a concise biography of Nashe.

Nashe had entered St John's College, Cambridge, circa 1581, and five years later earned his bachelor's degree. His colourful history at Cambridge is recapitulated in The Trimming of Thomas Nashe, Gentleman (1597), which represents itself as written 'by the high-tituled patron Don Richardo de Medico Campo, BarberChirurgion to Trinitie Colledge in Cambridge.' The polemic was likely written by Harvey, but the attribution is to his crony-barber, Richard Lichfield, whom Nashe had facetiously named as dedicatee of Saffron-Walden in the prior year. 'Litchfield' reports that Nashe's departure from Cambridge was precipitated by his contribution to a student play: 'suspecting himself that he should be stared for egregie dunsus, and not attain to the next Degree [MA], said he had commest enough, and so forsook Cambridge, being a Batchelor of the third yere'. ${ }^{21}$ Nashe's play is thought to have made importunate comments on the royal succession, and the prank to have been sufficiently serious to precipitate the dismissal of a co-author. Though Nashe claims in Saffron-Walden that he could have become a fellow of St John's, ${ }^{22}$ he departed the college in 1589 - the year he turned twenty-one, ended his minority and reached 'man's estate' - and was shown the gate without proceeding MA.

But how do we explain Feste's 'But when I came, alas! to wive ... With swaggering by could I never thrive'? So far as we know, Nashe never married. However, his Jack Wilton, having witnessed a final, grotesque act of violence, most certainly did marry 
his Diamante - and, yes, renounced his swaggering life: 'To such straight life did it thenceforward incite me that ere I went out of Bologna, I married my courtesan, performed many alms-deeds ... and feasted many days. ${ }^{23}$

Finally, what of the drunken tosspots who persisted in their revelry when he 'came unto my beds' - that is, neared death particularly as Jonson's recently discovered encomium for Nashe tells us he 'diedst a Christian faithfull penitent'? Could this be Nashe's lament that his fellow writers (tosspots) had profited nothing by his sudden conversion - much like Paul on the Damascus road - and still had drunken heads? Likely, Nashe's abrupt conversion suggested to Shakespeare the linking of Nashe and St Paul in Feste.

We don't know enough (yet) about Nashe's life and death to answer these questions. But we do know that Nashe led a windy, rainswept life. Professor Elam is correct when he deduces that 'At the end of its rapid journey through life, the song seems about to make an important statement about the world, but immediately drops the idea. ${ }^{24}$ Breaking off in mid-thought is emblematic for the sudden muzzling of Nashe in 1599. It is affecting, puzzling, poignant. In the silence that follows, Shakespeare's effigy of Nashe departs the stage. It is his third and last appearance. He will never return.

With the battle lines now carefully drawn - pitting Paul-FesteNashe against Malvolio-Harvey - we can move on to discovering the solution to one of Shakespeare's most debated, stubborn, and infuriating cruces, the 'fustian riddle' of M.O A.I.

\section{Notes}

1 Pharisees - 'separate ones' - were also legalists, debaters, students of and rigid upholders of the law, and zealots. They believed in the resurrection of the dead, free will (and predestination, sort of), and prayers three times a day including the Sh'ma. One can easily see how Paul, the Pharisee Christian-hater, could flip-flop and become a zealous Christian proselytizer.

2 In his Epistle to the Galatians, Paul says that after his conversion he immediately went to 'Arabia', by which some scholars believe he meant Petra in modern Jordan, then travelled to Damascus to teach.

3 Born in Lowestoft, Suffolk, Nashe attended Cambridge, moved to London, was on the Isle of Wight at Christmas 1593, and exiled himself to Great Yarmouth after the Isle of Dogges affray in 1597. Nashe 
also made a brief visit to antiquary Robert Cotton at Conington in Huntingdonshire in 1593. But in The Unfortunate Traveler his charming con-man protagonist engages in lusty, picaresque time-travel through France and Italy, often at the risk of his life. Though not held in great esteem today, the book is a landmark in English letters. In 1887 Jean Jules Jusserand (1855-1932) declared Nashe had been first to indicate 'the road that was to lead to the true novel ... to relate in prose a longsustained story, having for its chief concern: the truth ... No one, Ben Jonson excepted, possessed at that epoch, in so great a degree as himself, a love of the honest truth [realism]. With Nash, then, the novel of real life, whose invention in England is generally attributed to Defoe, begins.' Jean Jusserand, Le roman au temps de Shakespeare (Paris: Asnières, 1887), 347-8 (my translation). Defoe published his first novel, Robinson Crusoe, only in 1719 when Nashe had been dead 119 years.

4 For example: G. R. Hibbard, Thomas Nashe (London: Routledge and Kegan Paul, 1962).

5 But McKerrow reports that in a copy of The Hospital of Incurable Fooles (London: Edward Blount, 1600), a certain 'P.W.' has left a manuscript note: 'Tho. Nashe had some hand in this translation and it was the last thing he did as I heare.' See William E. Miller, 'The Hospitall of Incurable Fooles', Studies in Bibliography 16 (1963), 204-7.

6 R. Chris Hassel, Jr., catalogues a number of Feste's borrowings from the Epistles of Paul but does not detect the presence of Nashe. See Faith and Folly in Shakespeare's Romantic Comedies (Athens, GA: University of Georgia Press, 2011), 169-75.

7 Quoted in Katherine Duncan-Jones, “"They say a made a good end”, The Ben Jonson Journal3 (1996), 1-6.

8 J. J.M. Tobin, 'Gabriel Harvey in Illyria', English Studies 61 (1980), 321. Maurice Hunt, 'Thomas Nashe, The Unfortunate Traveller, and Love's Labour's Lost', Survey of English Literature 54 (Spring 2014), 297-314.

9 Nicholl detects Nashe behind the mask of Feste: 'If Nashe is [regarded as] a 'minor' author, or at any rate a flawed one, his stylistic influence was none the less major. His richly textured language is discernible in the comedies of Jonson and the journalism of Dekker, and is more subtly present in Shakespeare: in the Falstaff scenes, in the bitter clowning of Twelfth Night, and even in Hamlet' (108).

10 McKerrow, Nashe, III.192.7.

11 St Jerome, The Vulgate Preface to Paul's Letters, trans. Kevin P. Edgecombe, www.tertullian.org/fathers/jerome_preface_pauls_letters. htm (accessed 4 August 2011).

12 Sommers was certainly bright in living memory and would remain so for many years; as late as 1605 Samuel Rowley brought Sommers back 
to the stage in When You See Me You Know Me. And Sommers was the subject of two popular books, A Nest of Ninnies by Robert Armin (1608) and the anonymous A Pleasant History of the Life and Death of Will Summers (1676).

13 J. J. M. Tobin, 'Gabriel Harvey in Illyria', English Studies 61 (1980), 318-28. Professor Tobin was perhaps not the first to detect the Malvolio-Harvey connection. 'In 1962 G. R. Hibbard in his book on Nashe noted the analogy between Harvey and Malvolio without suggesting a satiric identity, and cited Muriel Bradbrook's recognition of a somewhat similar parallelism.' Tobin, in correspondence, 27 August 2012.

14 Tobin, 'Gabriel Harvey in Illyria', 318.

15 Ronald B. McKerrow, ed., The Works of Thomas Nashe, 5 vols (London: Sidgwick \& Jackson, 1904-19, repr. Oxford: Basil Blackwell, 1958), III.97-8.

16 Ibid., III.98.

17 Ibid., III.99. William Hacket (d. 1591) was a puritan who conspired to stage an ecclesiastical and civil coup d'état. Convicted of treason, he was hanged. Hacket believed himself the Messiah, which may account for the reference to crucifixion, an obvious invention of Nashe's.

18 Ibid., III.101.

19 Tobin, 'Gabriel Harvey in Illyria', 325.

20 A. W. Verity, ed., Twelfth Night, or What You Will, The Pitt Press Shakespeare for Schools, repr. (Cambridge: Cambridge University Press, 1961), 135.

21 The Trimming of Thomas Nashe, Gentleman in Alexander Balloch Grosart, ed., The Works of Gabriel Harvey (London: privately printed, 1884-85). Grosart, among others, believed Harvey to be the author.

22 McKerrow, Nashe, III.127.32-3.

23 Thomas Nashe, The Unfortunate Traveler, or the Life of Jack Wilton (London, 1594), 327.32.

24 Keir Elam, ed., Twelfth Night, The Arden Shakespeare, Series 3 (London: Bloomsbury, 2009), 354n 